FINANCIAL: Jurnal Akuntansi

Published by Program Studi Akuntansi STIE Sultan Agung

Volume 6-Nomor 1, Juni 2020, (Hlm 36-47)

ISSN-P: 2502-4574, ISSN-E: 2686-2581

Available online at: https://financial.ac.id/index.php/financial

\title{
PENGARUH DANA BAGI HASIL (DBH) PAJAK DAN BUKAN PAJAK TERHADAP ANGGARAN PENDAPATAN DAN BELANJA DAERAH (APBD) PEMERINTAH KOTA BOGOR TAHUN 2010 - 2017
}

\author{
Darwin Marasi Purba ${ }^{1)}$, Yansen Siahaan ${ }^{2)}$, Rizki Ahmad Fauzi ${ }^{3)}$ \\ ${ }^{1,3}$ Universitas Binaniaga Indonesia, ${ }^{2}$ Sekolah Tinggi Ilmu Ekonomi Sultan Agung \\ E-mail: ${ }^{1}$ mazmur.911516@gmail.com, ${ }^{2}$ yansensiahaan@stiesultanagung.ac.id, \\ 3hafari3327@gmail.com
}

\begin{abstract}
Abstrak
Penelitian ini bertujuan untuk membuktikan secara empiris pengaruh Dana Bagi Hasil Pajak dan bukan Pajak pada Anggaran Pendapatan dan Belanja Daerah di Pemerintah Kota Bogor - Jawa Barat. Populasi dalam penelitian ini adalah data Pendapatan Bagi Hasil Pajak Pemerintah Kota Bogor tahun 2010-2017. Metode analisis data menggunakan analisis statistik deskriptif, uji asumsi klasik dan regresi data panel yang diolah menggunakan program Eviews 7.2. Hasil penelitian ini menunjukkan bahwa dana bagi hasil pajak dan bukan pajak tidak memiliki pengaruh yang signifikan secara simultan pada Anggaran Pendapatan dan Belanja Daerah. Namun, hasil pengujian parsial menunjukkan bahwa Dana Bagi Hasil Pajak memiliki pengaruh signifikan sementara Dana Bagi Hasil bukan Pajak tidak memiliki pengaruh signifikan terhadap Anggaran Pendapatan dan Belanja Daerah di Pemerintah Kota Bogor.

Kata kunci: dana bagi hasil pajak, anggaran pendapatan dan belanja daerah
\end{abstract}

\section{THE INFLUENCE OF TAX AND NON-TAX REVENUE-SHARING FUNDS ON THE REGIONAL REVENUE AND EXPENDITURE BUDGET IN CITIES GOVERNMENT BOGOR PERIOD 2010-2017}

\begin{abstract}
This study aimed to get empirical evidence about the influence of Tax and non-Tax Revenue-Sharing Funds on the Regional Revenue and Expenditure Budget in Cities Government Bogor - West Java. Population of this research are data on Tax Revenue-Sharing Funding at Bogor City Government in 2010-2017. Methods of data analysis using descriptive statistical analysis, test classic assumptions and data panel regression were processed using by Eviews Version 7.2 programs. These results of research indicate that tax and non Tax Revenue-Sharing funds have no significant effect simultaneously on the Regional Revenue and Expenditure Budget. However, partial test results showed that the Tax Revenue-Sharing Fund has significant effect on the Regional Revenue and Expenditure Budget while non Tax Revenue Sharing fund is not significat effect on the Regional Revenue and Expenditure Budget.

Keywords: tax revenue-sharing fund, regional revenue and expenditure budget
\end{abstract}

Article History: Received: 21 Apr 2020 Revised: 29 Mei 2020 Accepted: 02 Jun 2020 


\section{PENDAHULUAN}

Otonomi daerah diartikan sebagai hak, kewajiban, dan wewenang secara otonom diberikan oleh Pemerintah Pusat kepada Pemerintah Daerah untuk mengatur dan mengurus sendiri kepentingan masyarakat setempat sesuai dengan peraturan perundang-undangan. Pelaksanaan otonomi daerah diatur dengan ketentuan Undang-Undang Nomor 22 Tahun 1999 tentang Pemerintah Daerah yang direvisi dengan Undang-Undang Nomor 32 Tahun 2004, dimana Pemerintah Daerah mengatur dan mengurus sendiri pemerintahan berdasarkan asas ekonomi dan tugas pembantuan agar terwujudnya kesejahteraan masyarakat melalui peningkatan pelayanan, pemberdayaan dan peran serta masyarakat, serta peningkatan daya saing daerah dengan memperhatikan prinsip daya saing daerah dengan memperhatikan prinsip demokrasi.

$$
\text { Efisiensi dan efektifitas }
$$

penyelenggaraan pemerintahan daerah perlu ditingkatkan dengan lebih memperhatikan aspek-aspek hubungan antar susunan pemerintah dan pemerintah daerah, potensi dan keanekaragaman daerah, peluang dan tantangan persaingan global dengan memberikan kewenangan yang seluasluasnya kepada daerah dalam kesatuan sistem penyelenggaraan pemerintahan negara.

Penetapan strategi yang tepat kian penting bagi suatu daerah yang sangat ditentukan oleh kondisi, potensi sumber daya yang dimiliki dan permasalahan pokok yang dihadapi oleh daerah tersebut. Beberapa daerah yang wewenangnya masih tetap dipegang oleh Pemerintah Pusat berdasarkan jumlah dan kualitas sumber daya yang tersedia dapat dimanfaatkan untuk mendukung upaya pencapaian tujuan dan sasaran pembangunan daerah sebagaimana diatur dalam Undang-Undang
Nomor 32 Tahun 2004 tentang Pemerintah Daerah (Soemantri, 2014).

Pendapatan domestik regional bruto (PDRB) suatu daerah menunjukkan seberapa besar aktivitas perekonomian secara keseluruhan. PDRB yang merupakan salah satu bentuk reformasi pada sistem pemerintahan didasarkan salah satu indikator atas harga konstan guna melihat keberhasilan pertumbuhan perekonomian di suatu wilayah otonomi daerah (Hapid, Halim dan Wulandari, 2015). Setiap daerah memiliki potensi dan faktor-faktor produksi dengan besaran PDRB yang bervariasi. Suatu daerah yang mampu melaksanakan otonomi dan desentralisasi yaitu: (1) memiliki kemampuan keuangan daerah, artinya adanya kewenangan dan kemampuan untuk mengali sumber-sumber keuangan, menggunakan, dan mengelola keuangan sendiri untuk membiayai pemerintahannya; dan (2) dengan tujuan Pendapatan Asli Daerah (PAD) sebagai sumber keuangan terbesar, suatu daerah harus memiliki ketergantungan kepada Pemerintah Pusat seminimal mungkin. Pemerintah Daerah dituntut untuk lebih mandiri untuk menentukan prioritas dan kepentingan masyarakat terhadap arah pembangunan daerah pada beberapa daerah yang memiliki potensi PAD yang rendah (Soleh dan Rochmansjah, 2010).

Dana Perimbangan yang bersumber dari Anggaran Pendapatan dan Belanja Negara (APBN) yang ditujukan dalam pelaksanaan kewenangan Pemerintah Daerah terdiri dari 3 (tiga) komponen yaitu Dana Alokasi Umum (DAU), Dana Alokasi Khusus (DAK) dan Dana Bagi Hasil (DBH). DBH itu sebagaimana diatur dalam Pasal 11 ayat (1) UU No.33/2004 bersumber dari Pajak Bumi dan Bangunan (PBB), Bea Perolehan Hak atas Tanah dan Bangunan (BPHTB), dan Pajak Penghasilan (PPh) 
Pasal 25 dan Pasal 29 Wajib Pajak Orang Pribadi Dalam Negeri dan serta PPh Pasal 21. Penetapan $\mathrm{PPh}$ Orang Pribadi menjadi komponen dari objek bagi hasil menjadi perolehan pajak di suatu daerah yang memiliki tingkat penerimaan sebagai basis pajak, hal ini ditujukan sebagai penyelaras dan kompensasi bagi daerah-daerah yang tidak memiliki sumber daya alam (Yusriadi, 2017).

Beberapa hasil penelitian yang menunjukkan kontribusi DAU, DAK, dana bagi hasil pajak dan bukan pajak serta PAD terhadap belanja modal dan APBD yakni: (1) Penelitian Wahyu Pamudji dan Willy Abdillah di tahun 2014 menguji faktorfaktor tersebut terhadap belanja modal Pemerintah Pemerintah Kabupaten/Kota di Provinsi Jawa Barat tahun 2008 - 2012 dengan pendekatan kuantitatif dan uji regresi berganda, dimana menunjukkan hasil bahwa pendapatan asli daerah, dana bagi hasil, dana alokasi umumberpengaruh signifikan terhadap belanja modal, sedangkan varibel dana alokasi khusus tidak berpengaruh signifikan terhadap belanja modal; (2) Penelitian Arda Rizki dan Dini Hapsari di tahun 2015 menguji faktor-faktor tersebut terhadap belanja daerah di Pemerintah Kabupaten / Kota Provinsi Jawa Barat tahun 2010-2012 dengan metode penelitian deskriptif dan verifikatif serta analisis regresi linear berganda, dimana menunjukkan hasil bahwa PAD, DAU, DBH berpengaruh signifikan terhadap belanja daerah sedangkan DAK tidak berpengaruh secara signifikan terhadap belanja daerah; (3) Penelitian Ida Bagus Made Agung Dwijatenaya dan Mutiara Kartika Dewi di tahun 2015 yang mengevaluasi dana bagi hasil untuk meningkatkan kesejahteraan masyarakat dengan metode deskriptif kuantitatif yang melibatkan 42 penduduk di Kecamatan
Tenggarong Kabupaten Kutai Kartanegara, dimana menunjukkan hasil bahwa responden cenderung setuju dana bagi hasil (DBH) mampu meningkatkan tingkat pendidikan, derajad kesehatan, tingkat investasi dan tata kelola pemerintahan yang baik serta mayoritas responden setuju agar DBH ditingkatkan dan menyatakan agar Undang Undang Nomor 33 Tahun 2004 direvisi; (4) Penelitian Arthaingan $\mathrm{H}$. Mutiha di tahun 2016 menganalisa kinerja keuangan dari Pemerintah Kota Bogor periode 2010 - 2014 dengan menggunakan analisa rasio seperti derajat desentralisasi, rasio kemandirian keuangan, rasio efektif pendapatan, rasio belanja langsung dibandingkan total belanja, rasio belanja tidak langsung terhadap total belanja, serta rasio pertumbuhan dengan metode deskriptif kuantitatif, dimana menunjukkan hasil bahwa Pemerintah kota Bogor sangat efektif dalam merealisasikan pendapatan asli daerahnya, serta memiliki rasio pertumbuhan yang positif. Namun Pemerintah kota Bogor masih memprioritaskan anggarannya dalam belanja tidak langsung dibandingkan dengan belanja langsung; dan (5) Penelitian Sri Mulyati Yusriadi di tahun 2017 yang secara spesifik menguji dana bagi hasil dan dana alokasi umum (DAU) pada 23 Kabupaten/Kota di Aceh dari tahun 2013 s.d. 2015 dengan teknik analisis regresi linear berganda, dimana hasil penelitian membuktikan dana bagi hasil dan dana alokasi umum masing-masing berpengaruh signifikan terhadap belanja daerah pada Pemerintah Kabupaten/Kota di Aceh.

$$
\text { Berdasarkan pertimbangan- }
$$
pertimbangan tersebut maka penelitian ini secara spesifik menguji kembali apakah dengan tanpa melibatkan faktor DAU, DAK, dan PAD serta hanya berfokus pada dana bagi hasil $(\mathrm{DBH})$ meriupakan dana 
bagi hasil yang bersumber dari pajak dan bukan pajak merupakan sumber Pemerintah Daerah khususnya di daerah-daerah yang memiliki potensi PAD yang tinggi dapat mengurangi ketergantungan terhadap pemerintah pusat atau sebaliknya sebagaimana diatur dalam Pasal 11 ayat (1) UU No.33/2004. Perbedaan penelitian dengan penelitian terdahulu adalah penelitian ini menggunakan subjek penelitian yang juga lebih spesifik yaitu Pemerintah Kota Bogor dengan menggunakan periode penelitian yang lebih panjang yaitu tahun 2010-2017. Oleh karena itu, penelitian ini diberi judul: "Pengaruh Dana Bagi Hasil Pajak dan Bukan Pajak terhadap Anggaran Pendapatan dan Belanja Daerah Pemerintah Kota Bogor Tahun 2010-2017".

\section{LANDASAN TEORI}

\section{Teori Agensi (Agency Theory)}

Menurut Scott (2015), teori agensi merupakan teori yang mendasari hubungan antara pemilik (principal) dengan pihak manajemen (agent) yang diperkenalkan oleh Jensen dan Meckling pada tahun 1976. Teori agensi dapat menimbulkan konflik keagenan. Konflik ini terjadi karena kemungkinan agent tidak bertindak sesuai dengan kepentingan principal (Purba, 2018). Berdasarkan Undang-Undang Pemerintah Daerah tahun 2004, Pemerintah Daerah menyelenggarakan urusan pemerintahan yang menjadi kewenangannya yang memisahkan dengan tegas antara fungsi pemerintah daerah (eksekutif) dengan fungsi perwakilan rakyat (legislatif). Berdasarkan pembedaan fungsi tersebut, eksekutif melakukan perencanaan, pelaksanaan, dan pelaporan atas anggaran daerah yang merupakan pelayanan kepada publik, sedangkan legislatif berperan aktif dalam melaksanakan legislasi, penganggaran, dan pengawasan.

\section{Teori Kepemilikan (Stakeholders' Theory)}

Teori kepemilikan sering dikaitkan dengan pihak-pihak atau lintas pelaku dan orang-orang yang memiliki rencana atau isu. Teori ini mendasari pemangku kepentingan baik kelompok atau organisasi dapat dipengaruhi dan mempengaruhi tindakan organisasi, tujuan, dan kebijakan dalam sistem sosial yang berlaku (Freeman:1982; Roberts: 1992, dalam Mianti, 2014). Birokrasi merupakan agen Pemerintah yang saat ini cenderung selfserving (kepentingan sendiri) dan memusatkan kekuasaan terhadap suatu perubahan. Dalam rangka penyelenggaraan otonomi daerah, APBD dijadikan pedoman dan tolok ukur dalam mengevaluasi kinerja Pemerintah Daerah. Akan tetapi, otonomi tidak dapat terlepas dari para stakeholders yang dalam penelitian ini Pemerintah Kota Bogor harus terlepas dari aspek politik sehingga peranan Pemerintah Daerah dalam memberikan pelayanan publik kian efisien dan efektif.

\section{Dana Bagi Hasil (DBH)}

Definisi Dana Bagi Hasil (DBH) yang merupakan dana yang bersumber dari pendapatan APBN yang dialokasikan kepada Daerah berdasarkan angka persentase tertentu untuk mendanai kebutuhan Daerah dalam rangka pelaksanaan Desentralisasi. DBH yang menjadi potensi sumber Pemerintah Daerah menurut Undang-Undang Nomor 33 Tahun 2004 tentang Perimbangan Keuangan antara Pemerintah Pusat dan Pemerintah Daerah. Dana Bagi Hasil (DBH) diklasifikasikan menjadi 2 (dua) yaitu: (1) Dana bagi hasil yang berasal dari pajak berupa Pajak Bumi dan Bangunan (PBB), Pajak Penghasilan (PPh) Pasal 21, Pasal 25 dan Pasal 29 wajib pajak orang pribadi dalam negeri, dan Bea Perolehan Atas Hak Tanah dan Bangunan 
(BPHTB); dan (2) Dana Bagi Hasil yang bersumber dari sumberdaya yang berupa bagi hasil sumber daya alam kehutanan, pertambangan umum, perikanan, pertambangan minyak bumi, pertambangan gas bumi, dan pertambangan panas bumi (Darise, 2009).

\section{Anggaran Pendapatan dan Belanja Daerah (APBD)}

Anggaran Pendapatan Dan Belanja Daerah merupakan rencana keuangan Pemerintah Daerah yang dibahas dan disetujui bersama oleh pemerintah dan DPRD yang ditetapkan dengan Peraturan Daerah (Darise, 2009). Struktur APBD terdiri dari Pendapatan Daerah, Belanja Daerah dan Pembiayaan Daerah yang merupakan satu kesatuan yang tidak dapat dipisahkan. APBD dapat dimanfaatkan untuk program-program pembiayaan daerah seperti penyertaan modal daerah, pembayaran pokok utang, transfer ke dana cadangan, penyertaan modal daerah dan sisa anggaran lebih tahun anggaran berjalan, hal ini disebut dengan Surplus Anggaran Daerah atau sebaliknya pembiayaan yang bersumber dari dana cadangan penerimaan pinjaman, hasil penjualan yang dipisahkan dan penerimaan kembali penerimaan pinjaman atau penerimaan piutang serta sisa lebih perhitungan anggaran lalu disebut dengan Defisit Anggaran Daerah.

\section{Kerangka Berpikir}

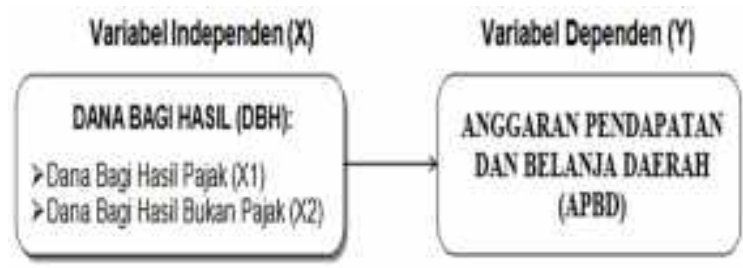

Diagram 1: Alur Pemikiran
Berdasarkan kerangka berpikir di atas, hipotesis penelitian dirumuskan sebagai berikut:

$\mathrm{H}_{1}$ = Dana Bagi Hasil Pajak berpengaruh terhadap Anggaran Pendapatan dan Belanja Daerah (APBD)

$\mathrm{H}_{2}=$ Dana Bagi Hasil Bukan Pajak berpengaruh terhadap Anggaran Pendapatan dan Belanja Daerah (APBD)

$\mathrm{H}_{3}$ = Dana Bagi Hasil (DBH) Pajak dan Bukan Pajak berpengaruh terhadap Anggaran Pendapatan dan Belanja Daerah (APBD)

\section{METODE}

\section{Jenis dan Sumber Data}

Data yang digunakan dalam penelitian ini adalah data sekunder yang merupakan data historis berupa data Dana Bagi Hasil (DBH) Pajak dan bukan Pajak Anggaran Pendapatan dan Belanja Daerah (APBD) Pemerintah Kota Bogor tahun 2010-2017 yang diperoleh dari Laporan Target dan Realisasi Penerimaan Pendapatan Daerah Kota Bogor. Adapun teknik pengumpulan data menggunakan: (1) dokumentasi yaitu pengumpulan data yang diperoleh dari instansi-instansi yang terkait yaitu pada Badan Pusat Statistik Jawa Barat; (2) studi pustaka yang dilakukan di STIE Bina Niaga; dan (3) wawancara yang ditujukan kepada narasumber atau pejabat daerah terkait.

\section{Operasionalisasi Variabel Penelitian}

Variabel Dana Bagi Hasil Pajak (X1) yang merupakan variabel independen pertama pada penelitian ini diukur berdasarkan perhitungannatural log dari total penerimaan DBH yang bersumber dari pajak yang terdiri dari bagi hasil Pajak Bumi dan Bangunan, Bea Perolehan Hak atas Tanah dan Bangunan, Pajak Penghasilan 
Pasal 25 dan Pasal 29 Wajib Pajak Orang Pribadi Dalam Negeri, dan Pajak Penghasilan Pasal 21.Variabel Dana Bagi Hasil Bukan Pajak (X2) yang merupakan variabel independen kedua pada penelitian ini diukur juga berdasarkan perhitungan natural log dari total penerimaan DBH yang bersumber dari sumber daya alam yang terdiri dari bagi hasil sumber daya alam kehutanan, pertambangan umum, perikanan, pertambangan minyak bumi, pertambangan gas bumi, dan pertambangan panas bumi. Variabel APBD (Y) yang merupakan variabel dependen diukur pada penelitian ini diukur berdasarkan perhitungan natural log dari total Anggaran Pendapatan dan Belanja Daerah Pemerintah Kota Bogor.

\section{Metode Analisis}

Metode analisis dalam penelitian ini menggunakan analisis regresi menggunakan data panel. Menurut Gujarati dan Porter (2013: Hal.240-251), analisis data panel terdapat 3 (tiga) metode pendekatan, yaitu:

(1) Common Effect: Pool Least Square (PLS), metode ini merupakan pendekatan ordinary least square (OLS) atau teknik kuadrat terkecil untuk mengestimasi model data panel; (2) Fixed Effect Model (FEM), metode FEM dapat diklasifikasikan menjadi 2 (dua), yaitu (i) model fixed effect satu arah; dan (ii) model fixed effect dua arah; dan (3) Random Effect Model (REM), Metode ini akan mengestimasi data panel dimana variabel gangguan mungkin saling berhubungan antar waktu dan antar individu. Pada model random fffect perbedaan intersep diakomodasi oleh error terms masing-masing perusahaan. Keuntungan menggunakan model ini dapat menghilangkan heteroskedastisitas. Model ini juga disebut dengan error component model (ECM) atau teknik generalized least square (GLS).
Beberapa pemilihan teknik estimasi untuk menentukan teknik yang paling tepat dalam mengestimasi parameter data panel, yaitu: (1) Uji Chow (Likelihood Ratio) merupakan pengujian untuk menentukan model fixed effect atau common effect yang paling tepat digunakan dalam mengestimasi data panel. Adapun dasar pengambilan keputusan yaitu: (a) Jika nilai F-statistik > F-tabel atau probabilitasnya < taraf signifikansi, maka $\mathrm{H}_{0}$ ditolak (fixed effect model) atau sebaliknya (common effect model), apabila model yang terpilih adalah fixed effect maka dilakukan pengujian selanjutnya, yaitu Uji Hausman; (2) Uji Hausmanmerupakan pengujian untuk menentukan model fixed effect atau modelrandomeffect yang paling tepat digunakan dalam mengestimasi data panel. Adapun dasar pengambilan keputusan yaitu: (a) Jika nilai chi-square statistik> nilai tabel distribusi chi-square dengan degree-of freedom (df) sejumlah variabel independen atau nilai probabilitas chi-square $<\alpha$ (nilai kritis), maka $\mathrm{H}_{0}$ ditolak (fixed effect model) atau sebaliknya (random effect model); dan (3) Uji Lagrange Multiplier(LM) merupakan pengujianuntuk mengetahui apakah model randomeffect lebih baik daripada metode common effect (OLS). Uji signifikasi random effect ini didasarkan pada nilai residual dari metode common effect yang dikembangkan oleh Breusch Pagan. Adapun rumus perhitungan LMstatistik yaitu:

$$
L M=\frac{n T}{2(T-1)}\left[\frac{\sum_{\mathrm{i}=1}^{\mathrm{n}}(\mathrm{T} \mathrm{e} \mathrm{i})^{2}}{\sum_{\mathrm{i}=1}^{\mathrm{n}} \sum_{\mathrm{t}=1}^{\mathrm{T}} \hat{\mathrm{e}}_{\mathrm{it}}^{2}}-1\right]
$$

\section{Keterangan:}

$\mathrm{n} \quad=$ jumlah individu;

$\mathrm{T}=$ jumlah periode waktu

$\mathrm{e}=$ residual metode common effect

(Sumber: Gujarati dan Porter, 2013) 
Jika nilai LM-statistik > nilai kritis statistik chi-square, maka $\mathrm{H}_{0}$ ditolak (random effect model) atau sebaliknya common effect model).

Bentuk persamaan regresi data panel yang dirumuskan dalam penelitian ini yaitu:

$$
\mathrm{Y}=\alpha+\beta 1 \mathrm{X} 1+\beta 2 \mathrm{X} 2+\grave{\mathrm{e}}
$$

Keterangan:

$\mathrm{Y}=$ Anggaran Pendapatan Dan Belanja Daerah (APBD)

$\mathrm{a}=$ Konstanta

$\beta_{1}=$ Koefisien Dana Bagi Hasil Pajak (X1)

$\beta_{2}=$ Koefisien Dana Bagi Hasil Bukan Pajak (X2)

$\grave{\mathrm{e}}=$ Faktor pengganggu (error)

Metode analisis regresiini mensyaratkan untuk melakukan uji asumsi klasik terlebih dahulu agar mendapatkan hasil regresi yang baik (Ghozali, 2016). Setelah model regresi yang diajukan lolos dari uji asumsi klasik, maka dapat dilanjutkan ke pengujian hipotesis dengan uji linearitas, uji koefisien determinasi ( $R$ square), uji simultan (Uji-F / ANOVA), dan uji parsial (Uji-t).

\section{HASIL DAN PEMBAHASAN}

Tabel 1.

APBD Pemerintah Kota Bogor

\begin{tabular}{lll}
\hline Tahun & APBD (Rp.) & $\begin{array}{l}\text { \% Kenaikan } \\
\text { (Penurunan) }\end{array}$ \\
\hline 2010 & Rp891.568.394.881,- & - \\
2011 & Rp1.112.519.204.515,- & 19,86 \\
2012 & Rp1.334.121.612.819,-- & 16,61 \\
2013 & Rp1.531.669.272.454,- & 12,90 \\
2014 & Rp1.753.515.632.927,- & 12,65 \\
2015 & Rp1.753.515.632.927,- & 0 \\
2016 & Rp2.158.083.504.950,- & 18,75 \\
2017 & Rp2.315.070.091.631,-- & 6,75 \\
\hline
\end{tabular}

Sumber: DPPKAD Kota Bogor (Agustus 2017)

Rata-rata APBD Pemerintah Kota Bogor tahun 2010-2017 mengalami peningkatan di setiap tahunnya dari
Rp891,568 miliar hingga Rp2,315 triliun. Peningkatan tertinggi terjadi APBD pada tahun 2010-2011 sebesar 19,86 persen dan peningkatan terendah terjadi pada APBD tahun 2016-2017. Dengan data ini, dapat diketahui bahwa kontribusi tertinggi dan terendah dari APBD Pemerintah Kota Bogor memiliki perbedaan yang cukup bervariasi.

Tabel 2.

Statistik Deskriptif Variabel Penelitian

\begin{tabular}{lccc}
\hline & $\mathbf{X 1}$ & $\mathbf{X 2}$ & $\mathbf{Y}$ \\
\hline Mean & 10,90345 & 10,32449 & 12,18666 \\
Median & 10,88396 & 10,30957 & 12,21454 \\
Maximum & 11,07394 & 10,46341 & 12,36456 \\
Minimum & 10,82468 & 10,23756 & 11,95015 \\
Std. Dev. & 0,083352 & 0,074423 & 0,141092 \\
Skewness & 1,124111 & 0,785020 & $-0,381522$ \\
Kurtosis & 3,169101 & 2,595683 & 2,070820
\end{tabular}

Jarque-Bera $\quad 1,694366 \quad 0,876167 \quad 0,481871$

Probability $\quad 0,428621 \quad 0,645272 \quad 0,785892$

Sum

$87,22759 \quad 82,5958997,49327$

SumSq.

Dev. $\quad 0,048633 \quad 0,0387710,139348$

Observation

\begin{tabular}{lcrr} 
s & 8 & 8 & 8 \\
\hline Sumber: Output Eviews 7 & (2018)
\end{tabular} Variabel APBD (Y) memiliki nilai rata-rata 12,18666 dengan nilai minimum dan maksimum masing-masing sebesar 11,95015 dan 12,36456. Variasi data APBD pada sampel 7 tahun (2010-2017) Pemerintah Kota Bogor relatif sangat besar karena nilai mean dibandingkan dengan nilai standar deviasi lebih besar dari 100\%.

Variabel Dana Bagi Hasil Pajak (X1) menunjukkannilai minimum dan maksimum masing-masing sebesar 10,82468 dan 11,07394. Variasi data Dana Bagi Hasil Pajak pada sampel 7 tahun (2010-2017) Pemerintah Kota Bogor relatif juga sangat besar karena nilai mean dibandingkan 
dengan nilai standar deviasi lebih besar dari $100 \%$.

Variabel Dana Bagi Hasil Bukan Pajak (X2) menunjukkan nilai minimum dan maksimum masing-masing sebesar 10,23756 dan 10,46341. Variasi data Dana Bagi Hasil Bukan Pajak pada sampel 7 tahun (2010-2017) Pemerintah Kota Bogor juga relatif sangat besar karena nilai mean dibandingkan dengan nilai standar deviasi lebih besar dari $100 \%$.

\section{Uji Asumsi Klasik}

\section{Uji Normalitas}

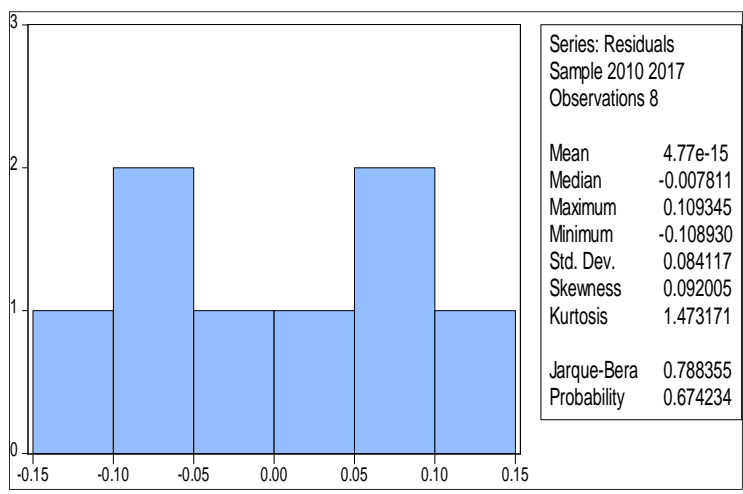

Diagram 2.

Histogram Uji Normalitas: Jarque-Bera Sumber: Output Eviews 7.2 (2018)

Hasil uji normalitas yang diperoleh dari output Eviews 7.2, besarnya nilai Jarque-Bera dan probabilitas masingmasing sebesar sebesar 0,788355 dan0,674234 adalah tidak signifikan sehingga $\mathrm{H}_{0}$ diterima ( $\mathrm{p}$-value $>0,05$ ). Oleh karena itu, dapat disimpulkan bahwa nilai residual telah memenuhi asumsi normalitas data.

\section{Uji Multikolinearitas}

Tabel 3.

Hasil Korelasi antar Variabel Independen

\begin{tabular}{cccc}
\hline & X1 & X2 & Y \\
\hline X1 & 1.000000 & -0.200435 & -0.709811 \\
X2 & -0.200435 & 1.000000 & -0.225260 \\
Y & -0.709811 & -0.225260 & 1.000000 \\
\hline \multicolumn{4}{l}{ Sumber: Output Eviews 7.2 (2018) }
\end{tabular}

Copyright (C) 2020, FINANCIAL: Jurnal Akuntansi
Hasil uji multikolinearitas yang diperoleh dari output Eviews 7.2, keseluruhan nilai variabel independen (X1 dan X2) memiliki nilai correlation matrix kurang dari $(<)$ 0,8 sehingga model regresi tidak mengindikasikan adanya masalah multikolinearitas antar variabel independen.

\section{Uji Heteroskedastisitas}

Tabel 4

Rangkuman Hasil Uji White

\begin{tabular}{ccc}
\hline & Nilai Obs*R- Probabilitas \\
F-Statistic & squared & Chi-square \\
\hline 1,103077 & 4,762143 & 0,3126 \\
\hline
\end{tabular}

Sumber: Hasil Pengolahan Data Eviews 7.2 (2018)

Hasil uji heteroskedastisitas yang diperoleh dari output Eviews 7.2, nilai obs*R-square untuk hasil uji white heterokedastisicy adalah 4,762143 dan probabilitas (chi-square $-\chi^{2}$ ) lebih besar dari (>) $\alpha=0,05$ sehingga $\mathrm{H}_{0}$ diterima. Model regresi tidak mengandung permasalahan heteroskedastisitas.

\section{4. Uji Autokorelasi}

Tabel 5.

Rangkuman Hasil Uji Breusch-Godfrey

\begin{tabular}{ccc}
\hline & Nilai Obs*R- Probabilitas \\
F-Statistic & squared & Chi-square \\
\hline 1,270822 & 3,66915 & 0,1597 \\
\hline
\end{tabular}

Sumber: Hasil Pengolahan Data Eviews 7.2 (2018)

Hasil uji autokorelasi yang diperoleh dari output Eviews 7.2, nilai probabilitas obs*R-square untuk hasil uji BreuschGodfrey Serial Correlation Langrange Multiplier (LM)adalah 0,1597 lebih besar dari (>) tingkat $\alpha=0,05$ sehingga $\mathrm{H}_{0}$ diterima. Model regresi tidak terdapat gejala autokorelasi. 
Uji Linieritas

Tabel 6.

Rangkuman Hasil Uji Ramsey

\begin{tabular}{ccc}
\hline F-Statistic & $\begin{array}{c}\text { Nilai Obs*R- Probabilitas } \\
\text { squared }\end{array}$ & \begin{tabular}{c} 
Signifikansi \\
\hline 1,446652
\end{tabular} \\
\hline
\end{tabular}

Sumber: Hasil Pengolahan Data Eviews 7.2 (2018)

Hasil uji linearitas yang diperoleh dari output Eviews 7.2, nilai probabilitas Fstatistik dari Ramsey Test sebesar 0,2954 > 0,05, maka residual model telah memenuhi asumsi linearitas.

Uji Hipotesis

\section{Uji Koefisien Determinasi}

Tabel 7.

Rangkuman Hasil Uji KoefisienDeterminasi

\begin{tabular}{ccc}
\hline Nilai $\mathbf{R}^{\mathbf{2}}$ & $\begin{array}{c}\text { Nilai Adjusted } \\
\mathbf{R}^{\mathbf{2}}\end{array}$ & $\begin{array}{c}\text { SE of the } \\
\text { Regression }\end{array}$ \\
\hline 0,644564 & 0,502930 & 0,099528 \\
\hline
\end{tabular}

Sumber: Hasil Pengolahan Data Eviews 7.2(2018)

Hasil uji koefisien determinasi yang diperoleh dari output Eviews 7.2, diperoleh nilai Adjusted $\mathrm{R}^{2}$ sebesar 0,502930 yang menunjukkan bahwa variabel-variabel independen yang terdiri dari Dana Bagi Hasil Pajak dan Bukan Pajak secara bersama-sama mampu menjelaskan variasi atau perubahan pada Anggaran Pendapatan dan Belanja Daerah (APBD) sebesar 50,29\% sedangkan $49,71 \%$ dijelaskan oleh variabel lain di luar model yang dibentuk atau variabel lain yang tidak diikutsertakan dalam penelitian ini.

\section{Uji Simultan (F-Test)}

Tabel 8.

Rangkuman Hasil Uji Simultan

\begin{tabular}{ccc}
\hline Probabilitas F-Statistic & $\boldsymbol{\alpha}$ & Kesimpulan \\
\hline 0,075319 & 0,05 & Ha Diterima
\end{tabular}

Sumber: Hasil Pengolahan Data Eviews 7.2 (2018)

Hasil uji simultan (ANOVA) yang diperoleh dari output Eviews 7.2, diperoleh nilai probabilitas F-hitung sebesar 0,075319 lebih besar (>) dari alpha $5 \%$ sehingga $\mathrm{H}_{0}$ diterima. Dengan demikian, variabel Dana Bagi Hasil (DBH) secara simultan tidak berpengaruh signifikan terhadap Anggaran Pendapatan dan Belanja Daerah (APBD).

\section{Uji Parsial (t-Test)}

Tabel 9

Rangkuman Hasil Uji Parsial

\begin{tabular}{ccccc}
\hline Hipotesis Alternatif & $\begin{array}{c}\text { Nilai } \\
\text { Koefisien }\end{array}$ & $\begin{array}{c}\text { Nilai } \\
\text { t-Statistics }\end{array}$ & $\begin{array}{c}\text { Signifikansi } \\
\text { Probabilitas }\end{array}$ & Kesimpulan \\
\hline Nilai Konstan & 34,19866 & 8,020583 & 0,0080 & \\
$\begin{array}{c}\text { H1: DBH Pajak } \rightarrow \text { APBD } \\
\text { H2: DBH Bukan Pajak } \rightarrow\end{array}$ & $-1,331425$ & $-2,890233$ & 0,0342 & Ha Diterima \\
APBD & $-0,725932$ & $-1,407024$ & 0,2184 & Ha Ditolak \\
\hline
\end{tabular}

Sumber: Hasil Pengolahan DataEviews 7.2(2018)

Berdasarkan hasil Output Eviews 7.2 yang dihasilkan, maka dapat dibuat hasil persamaan regresi berikut ini: $Y=30,19866-1,331425 X 1-0,725932 X 2+$ è

Dari hasil persamaan regresi di atas, dapat diartikan bahwa variabel Anggaran Pendapatan dan Belanja Daerah (Y) dalam bentuk natural log dipengaruhi oleh variabel independen (Dana Bagi Hasil - DBH Pajak dan Bukan Pajak) dengan penjelasan sebagai berikut: DBH Pajak (X1) memiliki nilai koefisien $\beta$ sebesar -1,331425. Artinya jika variabel independen lainnya bernilai tetap dan variabel Dana Bagi Hasil Pajak 
mengalami kenaikan atau peningkatan, maka Anggaran Pendapatan dan Belanja Daerah akan mengalami penurunan sebesar 1,331425 satuan.

DBH Bukan Pajak (X2) memiliki nilai koefisien $\beta$ sebesar 0,725932 . Artinya jika variabel independen lainnya bernilai tetap dan variabel Dana Bagi Hasil Bukan Pajak mengalami kenaikan atau peningkatan, maka Anggaran Pendapatan dan Belanja Daerah akan mengalami penurunan sebesar 0,725932 satuan.

\section{Pembahasan}

Berdasarkan hasil uji hipotesis uji-t pada Tabel 9, maka pembahasan hasil penelitian yang dimaksud dikaitkan dengan teori maupun hasil dari penelitian terdahulu adalah sebagai berikut:

1. Hipotesis pertama menyatakan bahwa Dana Bagi Hasil Pajak berpengaruh signifikan terhadap APBD. Berdasarkan perhitungan analisis regresi berganda, diperoleh nilai koefisien regresi sebesar $-1,331425$ dengan probabilitas sebesar 0,0342. Hasil pengujian ini menunjukkan bahwa Dana Bagi Hasil Pajak terbukti berpengaruh signifikan terhadap APBD. Hasil penelitian ini mendukung teori agensi (agency theory), dimana Pemerintah Daerah kota Bogor selaku eksekutif melakukan perencanaan, pelaksanaan, dan pelaporan atas anggaran daerah. Hasil penelitian ini mendukung penelitian Pamudji dan Abdillah (2014), Rizki dan Hapsari; Dwijatenaya dan Dewi (2015) serta Yusriadi (2017) yang menunjukkan hasil bahwa dana bagi hasil berkontribusi terhadap belanja modal dan daerah serta peningkatan Dana Bagi Hasil (DBH).
2. Hipotesis kedua menyatakan bahwa Dana Bagi Hasil bukan Pajak berpengaruh signifikan terhadap APBD. Berdasarkan perhitungan analisis regresi berganda, diperoleh nilai koefisien regresi sebesar -0,725932 dengan probabilitas sebesar 0,2184. Hasil pengujian ini tidak mendukung penelitian Pamudji dan Abdillah (2014), Rizki dan Hapsari; Dwijatenaya dan Dewi (2015) serta Yusriadi (2017) yang tidak membuktikan pengaruh Dana Bagi Hasil bukan Pajak terhadap APBD. Dana Bagi Hasil bukan Pajak pada penelitian ini tidak memiliki kontribusi terhadap APBD, hal ini membuktikan bahwa DBH bukan pajak yang merupakan bagian dari dana perimbangan mungkin lebih didominasi oleh jenis-jenis sumber lainnya.

3. Hipotesis ketiga menyatakan bahwa Dana Bagi Hasil (DBH) Pajak dan bukan Pajak tidak berpengaruh signifikan secara simultan terhadap APBD. Berdasarkan perhitungan uji simultan, diperoleh nilai signifikansi Fstatistik lebih besar dari 0,05. Artinya, semua variabel independen yang meliputi Dana Bagi Hasil Pajak dan bukan Pajak tidak cukup memberikan pengaruh terhadap APBD walaupun diperkuat dengan korelasi sebesar $50,29 \%$ variasi APBD ditentukan oleh Dana Bagi Hasil (DBH) dan sisanya $49,71 \%$ dipengaruhi oleh faktor-faktor lainnya, artinya faktor-faktor lain selain Dana Bagi Hasil (DBH) yang tidak diikusertakan pada penelitian ini memiliki kontribusi yang cukup penting dalam menerangkan model variabel Anggaran Pendapatan dan Belanja Daerah (APBD) 


\section{SIMPULAN DAN SARAN}

\section{Kesimpulan}

Berdasarkan hasil penelitian dan pembahasan, maka penelitian ini dapat disimpulkan sebagai berikut:

1. Dana Bagi Hasil Pajak terbukti berpengaruh signifikan terhadap APBD.

2. Dana Bagi Hasil bukan Pajak tidak terbukti berpengaruh signifikan terhadap APBD.

3. Dana Bagi Hasil Pajak dan Bukan Pajak tidak terbukti berpengaruh signifikan secara simultan terhadap APBD.

\section{Saran}

Saran pada penelitian ini diantaranya:

1. Bagi regulator dan Pemerintah, penelitian ini dapat memberikan masukan dalam merumuskan alokasi APBN dan kebijakan-kebijakan yang berkaitan dengan pelimpahan kewenangan kepada daerah otonom.

2. Bagi instansi terkait, hasil penelitian ini dapat membantu Pemerintah Daerah dalam pengambilan keputusan pengelolaan keuangan khususnyayang berkaitan dengan penggunaan Dana Perimbangan yaitu Dana Bagi Hasil (DBH) Pajak dan Bukan Pajak.

3. Bagi peneliti selanjutnya, diharapkan dapat menambahkan variabel lainnya untuk menguji pengaruhnya terhadap Anggaran Pendapatan dan Belanja Daerah (APBD), seperti Dana Alokasi Umum dan Khusus serta Pendapatan Asli Daerah (PAD), sehingga dapat memperbaiki temuan penelitian ini yang tidak membuktikan pengaruh secara simultan atas Dana Bagi Hasil Pajak dan Bukan Pajak terhadap Anggaran Pendapatan dan Belanja Daerah (APBD) dan dapat digunakan sebagai acuan untuk riset-riset mendatang.

\section{DAFTAR PUSTAKA}

Chabib Sholeh dan Heru Rochmansjah, 2010, Pengelolaan Keuangan dan Aset Daerah Sebuah Pendekatan Struktural Menuju Tata Kelola Pemerintahan Yang Baik. Bandung: Fokusmedia.

Darise, Nurlan. 2009. Pengelolaan Keuangan pada Satuan Kerja PerangkatDaerah (SKPD) dan $B L U$. Jakarta: Indeks.

Dwijatenaya, Ida Bagus Made Agung dan Mutiara Kartika Dewi. (2015). Evaluasi Dana Bagi Hasil untuk meningkatkan kesejahteraan masyarakat. Jurnal Badan Penelitian dan Pengembangan Daerah - Gerbang Etam. 9 (2), 78-87.

Ghozali, Imam. (2016). Aplikasi Analisis Multivariate Dengan Program: IBM SPSS 23. Edisi $\mathrm{Ke}-8$. Semarang: Badan Penerbit Universitas Diponogoro.

Gujarati, Damodar N. dan Porter, Dawn C. Porter. 2013. Dasar-Dasar Ekonometrika / Basic Econometris, Terjemahan: Mangunsong, R.C. Edisi Ke-5. Jakarta: Salemba Empat.

Hapid, Muh. Halim. dan Wulandari, Y. (2015). Pengaruh Dana Alokasi Khusus, Dana Bagi Hasil dan Dana AlokasiUmum terhadap Anggaran Pendapatan dan Belanja Daerah Kabupaten Luwu. Jurnal Ekonomi Pembangunan. 2(1), 1-7.

Mianti, R. (2014). Analisis Kinerja Keuangan Pemerintah Daerah SeProvinsi Bengkulu Sepuluh Tahun Terakhir. Skripsi Universitas Bengkulu: Bengkulu.

Mutiha, Arthaingan H. (2016). Analisis Kinerja Pemerintah Daerah Kota Bogor Tahun Anggaran 20102014. Jurnal Vokasi Indonesia. 2 (2), 105-121.

Pamudji, Wahyu dan Willy Abdillah. (2014). Pendapatan Asli Daerah, Dana Bagi Hasil Pajak dan Bukan 
Pajak, Dana Alokasi Umum dan Dana Alokasi Khusus dan Belanja Modal pada Kabupaten Kota Provinsi Jawa Barat. Jurnal Riset Akuntansi dan Perpajakan. 1 (2), 149-159.

Purba, Darwin M. (2018). The Influence Of Earnings Management, Audit Quality, and CEO Duality On The Tax Avoidance. The Accounting Journal of Binaniaga. 3 (1), 25-38.

Rizki, A. dan Dini Hapsari. (2015). Pengaruh Pendapatan Asli Daerah (PAD), Dana Alokasi Umum (DAU), Dana Bagi Hasil (DBH) dan Dana Alokasi Khusus (DAK) terhadap Belanja Daerah (Studi pada Pemerintah Provinsi Jawa Barat Tahun 2011-2012). $e$ Proceeding of Management. 2 (3), 3153-3160.

Scott, W.R. (2015). Financial Accounting Theory $\left(7^{\text {th }} e d\right)$. New Jersey: Prentice-Hall International, Inc.

Soemantri M, HRT Sri (2014). Otonomi Daerah. Bandung: Remaja Rosdakarya.

Undang-Undang Republik Indonesia Nomor 32 Tahun 2004 tentang Pemerintah Daerah.

Undang-Undang Republik Indonesia Nomor 33 Tahun 2004 tentang Perimbangan Keuangan Antara Pemerintah Pusat dan Pemerintah Daerah.

Yusriadi, Sri Mulyati. (2017). Dana Bagi Hasil Dan Dana Alokasi Umum Terhadap Belanja Daerah Pada Provinsi Aceh. Jurnal Ekonomi dan Bisnis. 1 (2), 211-220.
PROFIL BIODATA

Darwin Marasi Purba merupakan dosen akuntansi di Universitas Binaniaga Indonesia.

Yansen Siahaan merupakan seorang doktor pada Program Studi Ilmu Akuntansi. Saat ini beliau menjabat sebagai Ketua Program Studi Sarjana Akuntansi di STIE Sultan Agung.

Rizki Ahmad Fauzi merupakan dosen akuntansi di Universitas Binaniaga Indonesia. 